УДК 378.016

DOI: $10.15330 /$ esu. $14.155-159$
Ніна Зверєва,

аспірант, Харківський національний педагогічний університет імені Г.С. Сковороди

(м. Харків, Україна)

Nina Zvierieva,

Post-graduate student, H.S. Skovoroda Kharkiv

National Pedagogical University

(Kharkiv, Ukraine)

zvereva0104@gmail.com

\title{
СУЧАСНІ ПІДХОДИ ДО ФОРМУВАННЯ КОМУНІКАТИВНОЇ КУЛЬТУРИ ВИКЛАДАЧА
}

\section{MODERN APPROACHES TO THE FORMING OF LECTURER'S COMMUNICATIVE CULTURE}

У статті йдеться про комунікативну культуру викладача як складник його фахової компетентності. 3'ясовано підходи до визначення поняття “комунікативна культура" та здійснено аналіз ї основних показників. Розкрито сучасні підходи до формувания ивого складного феномена. У процесі дослідження з'ясовано, ио комунікативна культура викладача розглядається як складне особистісне утворення, синтез узаємопов'язаних якостей особистості (а саме: зиань, умінь, навичок, способів організачії комунікативної діяльності), необхідних для якісного та ефективного спілкування зі студентами та розробку ефективних навчально-педагогічних ситуачій, створения сдиного якісно нового мовноосвітнього середовища. Педагогічна комунікаиія синхронно реалізуе комунікативну, перчептивну та інтерактивну функиії, використовуючи при цьому всю сукупність вербальних, образотворчих, символічних і кінетичних засобів. На сучасному етапі найбільи дієвими підходами до формування комунікативної культури визначено компетентнісний та синергетичний.

Ключові слова: комунікація, культура, компетентність, підхід, система.

The article deals with the communicative culture of the teacher as a component of his professional competence. The approaches to the definition of "communicative culture" and their main indicators are analyzed. The modern approaches to the formation of this complex phenomenon are revealed. In the course of the study it was found that the communicative culture of the teacher is considered as a complex personal formation, the synthesis of interrelated personality traits (namely: knowledge, skills, ways of organizing communicative activities), which are necessary for high-quality and effective communication with students and the development of effective educational and pedagogical situations, the creation of a unified qualitatively new language and educational environment. The analysis of scientific and pedagogical literature proves that researchers from various fields of science (teachers, psychologists, linguists) share the view that the communicative culture of a teacher based on linguistic culture determines the potential of the whole system of education, and also affects on the development of the student's personality. The content of the professional activity of the modern teacher puts forward a number of specific requirements that make them develop certain personal qualities as professionally significant, necessary and compulsory. It is proved that today the problem of mastering a free, truly cultural word is especially relevant and important for those who use it as the main tool of their profession, especially for teachers whose language is not only the main tool of professional activity, but also a model that is consciously or unconsciously assimilated, perceived and distributed. Pedagogical communication synchronously implements communicative, perceptual and interactive functions, using at the same time the whole set of verbal, visual, symbolic and kinetic means. At the present stage, the most effective approaches to the formation of a communicative culture have been determined competence and synergy.

Key words: communication, culture, competence, approach, system. 
Постановка проблеми. Значення реальної щоденної практики мовної діяльності педагога під час оволодіння комунікативно-мовною культурою важко переоцінити. Міжособистісні взаємодії, контакти широкого спектра (ділові, професійні, міжособистісні), вимагають від учителя сучасної школи універсальної здатності до відтворення маси всіляких висловлювань - і в усному, і в писемному мовленні. Особливої значущості сьогодні набуває підготовка сучасного фахівця до широкої практики усного та писемного мовного спілкування, бо примітивна комунікація знижус якість національної мовленнєвої культури в засобах масової інформації, у художній літературі, у публіцистиці й повсякденному спілкуванні носіїв мови. Комунікативна спрямованість у процесі вивчення української мови не тільки слугує практичною метою - формування навичок спілкування і мовлення особистості, а й розвиває їі загальну освітню культуру через мову. На жаль, значний прогрес у царині інформаційно-комунікативних технологій не ініціював механічного підвищення людської свідомості й не вплинув безпосередньо на розвиток мислення й мови. Організований процес із розвитку комунікативної культури гарантує не тільки розвиток базових особистісних якостей майбутнього педагога, що залежать від мислення і мовлення особистості, але й розвиток якісних рівнів соціалізації людини.

Аналіз останніх досліджень. Різні аспекти формування комунікативної компетентності майбутніх фахівців достатньо широко висвітлені в працях Н. Волкової, Ю. Смельянова, В. Захарова, І. Зимньої, Н. Кузьміної, К. Слесик, С. Петрушина, Л. Петровської, Є. Прозорова, О. Сидоренка, В. Семиченко, Л. Ткаченко, Л. Філатової та інших. Грунтовні дослідження в цій галузі здійснили й представники зарубіжних наукових шкіл:, Л. Бахман, М. Кенел В. Купах, А. Палмер, М. Свейнта, Б. Шпітсберг та інші. Однак постійно з'являються нові напрями досліджень комунікації, а значить розширюється коло питань, які потребують уточнень або нових підходів до вирішення вже дослідженого.

Мета статті - розкрити потенційні можливості сучасних підходів (компетентнісного та синергетичного) у процесі формування комунікативної культури сучасного педагога.

Виклад основного матеріалу. Основними завданнями розвитку мовлення $\epsilon$ побудова вільних, коректних, доречних і логічних усних висловлювань, а також уміння створювати письмові тексти адекватних стилів i жанрів, цьому повинен навчити ЗВО. Але навчальні заклади сьогодні не завжди мають варіативні цільові освітні програми, що забезпечують високий результат у розвитку комунікативномовленнєвих умінь майбутнього вчителя, а також не завжди мають методичні та науково-практичні дослідження, що аналізують відносини між думкою і словом, необхідні сучасному педагогу, який забезпечує становлення нових генетичних рівнів мислення й мови. Важливою категорією педагогічної культури майбутнього педагога $\epsilon$ комунікативно-мовленнєва компетентність. Джерелом мотивації до самостійної діяльності студента є поставлені цілі - тобто, образ можливого (як прообраз того, що здійсниться), а засобами можуть бути окремі дії в напрямі проміжних цілей і iї результатом - переживання відносин, що складаються в суб'єкта зі світом.

Отже, комунікативно-мовленнєва діяльність педагога - це діяльність, заснована на педагогічній етиці, повазі й самоцінності дій, що має колективнорозподільний характер між суб’єктами взаємодії й спрямованістю із певною метою формування комунікативних якостей, необхідних для спілкування. Однією 3 
характеристик сучасного педагога $\epsilon$ його професійна культура, необхідним складником якої є комунікативно-мовленнєва компетентність. Розвиток професіоналізму в майбутнього педагога відбувається, зокрема й на основі комунікативномовленнєвих умінь.

Соціальне замовлення в галузі професійної педагогічної освіти диктує зростання міжкультурних, міжнаціональних контактів i всіляких соціальних узаємин: сьогодні суспільство висуває високі вимоги до комунікативно-мовних якостей учителя, які дозволяють йому бути конкурентоспроможним у нових політичних і соціально-економічних умовах - і в освіті, i на ринку праці, i в соціумі. Це стосується вчителя початкових класів, який, нарівні з умінням орієнтуватися в інформаційному просторі, повинен займатися самоосвітою, поповнюючи необхідні знання, володіти навичками самопрезентації, мобільністю, умінням вирішувати нестандартні комунікативні завдання. "Учитель є організатором середовища, яке виховує й управляє не тільки пізнавальними процесами свого учня, а й основними важелями соціальної ситуації його розвитку. В основі виховання - цілеспрямованість i навмисне вироблення нових форм поведінки й діяльності учня, що визначає планомірну організацію його поетапного розвитку" [3, с. 23].

На нашу думку, комунікативно-мовленнєва компетентність - це категорія оцінна, що характеризує людину як суб'єкта певного соціуму, передбачає глибоке розуміння суті комунікативних завдань, знання змісту теми спілкування, наявність досвіду в певній галузі, активне його використання, уміння добирати комунікативномовленнєві засоби, адекватні конкретним обставинам місця й часу, почуття відповідальності за досягнуті результати; здатність учитися на помилках і вносити корективи в процес досягнення комунікативних цілей.

Серед низки сучасних підходів, що можуть бути успішно застосованими в процесі формування комунікативної культури, варто виділити компетентнісний. Компетентнісний підхід у формуванні комунікативно-мовленнєвої компетенції, віддзеркалений у державних професійних стандартах та відповідній методичній літературі, дозволяє стверджувати, шо мовна особистість має володіти низкою ключових компетентностей. $\mathrm{y}$ науковому контексті поєднання термінів “комунікативно-мовленнєва компетентність" уперше було використано в руслі соціальної психології (від лат. competens - “здатний”) - здатність установлювати й підтримувати ефективні контакти 3 іншими людьми при наявності внутрішніх ресурсів (знань і умінь). У педагогічних словниках (О. Альмерот, Л. Бірюк, С. Гончаренко) поняття “компетентність" як самостійна семантична мовна одиниця трактується в значенні “рівень володіння певною галуззю знань” або "як загальна здатність що базується на знаннях, уміннях, навичках, досвіді, цінностях, здібностях, набутих завдяки навчанню" [1, с. 71]. Основними компетентностями, яких потребує сучасне життя $є$ такі: соціальні (здатність брати на себе відповідальність, участь у суспільному прийнятті рішень, у функціонуванні та розвитку демократичних інститутів суспільства); полікультурні (пов'язані з життям у полікультурному суспільстві передбачають розуміння несхожості людей, взаємоповагу до їх мови, релігії, культури тощо); інформаційні (зумовлені зростанням ролі інформації у сучасному суспільстві й передбачають оволодіння інформаційними технологіями); саморозвитку та самоосвіти (потреба і готовність постійно вдосконалюватися як у професійному, так і в особистісному плані). Окремо виділяється комунікативна компетентність, що полягає у досконалому володінні вербальними і невербальними засобами 3 метою побудови ефективної комунікації. Практико-теоретичне 
осмислення компетентнісного підходу в професійній підготовці майбутнього педагога почалося $з$ досліджень комунікативної методики (О. Бистрова, Т. Донська, Ю. Караулов, С. Львова, М. Разумовська, I. Муштавинська, І. Осмоловський, А. Хуторськой та інші). У роботах Н. Бібік, О. Бистрової, Р. Львова, О. Савченко, Л. Черепанової визначення компетенції пов'язане 3 сукупністю спеціальних i загальнопредметних знань, умінь, навичок, способів діяльності, а також ціннісних мотивів діяльності, сформованих у школярів унаслідок вивчення ними предметної освітньої галузі. При цьому поняття "компетенція" в деяких джерелах визначається як норма, а “компетентність” - як особистісні якості (сукупність якостей) суб’єкта відповідно до будь-якої його діяльності, як певна характеристика особистості, орієнтованої в темі.

У нормативних документах щодо підготовки сучасного педагога в поняття “комунікативна компетенція" закладено такі істотні показники: обізнаність лінгвістичної теорії, усвідомлення ऑiі як системи правил і загальних приписів, що регулюють уживання засобів мови в мовленні; знання теорії, володіння основними видами мовленнсвої діяльності; володіння основними мовними (пізнавати, класифікувати тощо) й мовленнєвими (вибирати, актуалізувати тощо) уміннями; здатність аналізувати мовну ситуацію й відповідно до неї обирати програму (i вербальну, і невербальну) поведінки. Значна частина наукових праць свідчить про те, що комунікативно-мовленнєву компетентність студента найкраще аналізувати за його навчальною діяльністю. Але “комунікативна компетентність студента виступає як складне особистісне утворення, що несе певне смислове навантаження характеристики суб'єкта" [2, с. 19-22]. Низка вчених згодні з тим, що визначальною умовою для формування комунікативно-мовленнєвої компетентності майбутніх педагогів $€$ організація в навчальному процесі комунікативних ситуацій, за яких викладач ЗВО створює комунікативну взаємодію зі студентами й між студентами, оцінюючи результати роботи через навчання.

Отже, компетентнісний підхід до формування комунікативної компетентності майбутнього педагога дозволяє: узгодити цілі навчання із власними. Iз кожним новим поколінням студентів значення цього моменту зростає, бо кожне нове покоління стає більш самостійним, незалежним від поглядів і суджень педагогів, здатним до формування власних ідей; підвищити ступінь мотивації навчання у ЗВО передусім за рахунок усвідомлення його користі для сьогоднішнього й подальшого життя; полегшити працю викладача за рахунок поступового підвищення ступеня самостійності й відповідальності студента у формуванні комунікативної компетентності; залучити студента до процесу самоосвіти; розвантажити студентів не за рахунок механічного скорочення змісту, а за рахунок підвищення індивідуальної освіти, перенесення уваги до способів роботи з інформацією і зміни мотивації. Зазначені показники сприяють формуванню комунікативної компетентності як показника відповідної культури.

Не менш дієвим сучасним підходом до формування комунікативної компетентності майбутнього педагога $\epsilon$ синергетичний. Артпедагогічний словник визначає синергетику як науку, “що досліджує процеси переходу складних систем із неупорядкованого стану в упорядкований і відкриває такі зв'язки між елементами цієї системи, завдяки яким їхня дія у межах системи є ефективнішою за просте додавання ефектів дії кожного окремого елемента" [1, с. 125]. Відповідно, ми трактуємо синергетичний підхід до формування комунікативної компетентності як гармонійне поєднання знань про мовну систему та реалізацію мовленнєвих актів, що 
сприяють побудові конструктивної комунікативної взаємодії. Основи синергетичного підходу були закладені в психологічних роботах Б. Ананьєва, Л. Виготського, О. Леонтьєва, С. Рубінштейна. Вони розглядали особистість як суб'єкт діяльності, формуючись у діяльності й у спілкуванні з іншими людьми, визначає характер цієї діяльності й спілкування. Синергетичний підхід у своєму особистісному компоненті передбачає, що в центрі навчання знаходиться саме навчання, його мотиви, цілі, неповторний психологічний склад, тобто студент як особистість. Беручи за основу інтереси того, хто навчається, рівня його знань і умінь, викладач визначає навчальну мету заняття і формує, спрямовує й коригує весь освітній процес із метою розвитку особистості. Особистісний компонент синергетичного підходу передбачає, що в процесі викладання будь-якого навчального предмета максимально враховуються національні, гендерні, індивідуально-психологічні, статусні особливості того, хто навчається. Цей облік здійснюється через зміст i форму самих навчальних завдань, через характер спілкування зі студентом. Таким чином, синергетичний підхід у формуванні комунікативної культури сучасного педагога дозволяє інтегрувати різноаспектні (мовні, мовленнєві, особистісні) якості з метою одержання якісно нового результату.

Висновки. Отже, формування комунікативної культури сучасного педагога $\epsilon$ не лише вимогою часу, а й важливим компонентом його професійного становлення. У процесі формування комунікативної культури доцільно використовувати як традиційні підходи (індивідуальний, особистісно-орієнтований), так і сучасні компетентнісний та синергетичний, що дозволяють структурувати увесь процес професійної підготовки, підпорядкувати його провідним цілям, дати поштовх до творчого розкриття потенційних комунікативних можливостей майбутнього педагога.

\section{Література}

1. Артпедагогічний словник: навчальний посібник для студентів факультету початкової освіти. [автори-упорядники Альмерот О.В. Бірюк Л.Я.]. 512 с.

2. Балдынюк Д. И. Системное исследование культуры общения педагога (теоретический аспект) : автореф. дис. ... канд. пед. наук: 13.00.01. Киев, 1989. 24 с.

3. Исаев И.Ф. Профессионально-педагогическая культура преподавателя: учеб. пособ. для студ. высш. учеб. заведений. - Москва : Академия, 2002. 208 с

\section{References}

1. Artpedahohichnyy slovnyk: navchalnyy posibnyk dlya studentiv fakultetu pochatkovoyi osvity. [avtory-uporyadnyky Almerot O.V. Biryuk L.YA.]. 512 s.

2. Baldynyuk D. I. Sistemnoye issledovaniye kul'tury obshcheniya pedagoga (teoreticheskiy aspekt) : avtoref. dis. ... kand. ped. nauk: 13.00.01. Kiyev, 1989. $24 \mathrm{~s}$.

3. Isayev I.F. Professional'no-pedagogicheskaya kul'tura prepodavatelya: ucheb. posob. dlya stud. vyssh. ucheb. zavedeniy. - Moskva : Akademiya, 2002. 208 s.

Одержано статтю: 2.10 .2018

Прийнято до друку: 5.11.2018 